\title{
Patterns of diversity and abundance of fungus-growing ants (Formicidae: Attini) in areas of the Brazilian Cerrado
}

\author{
Heraldo L. Vasconcelos ${ }^{1}$; Bruna B. Araújo ${ }^{1} \&$ Antonio J. Mayhé-Nunes ${ }^{2}$ \\ 1 Instituto de Biologia, Universidade Federal de Uberlândia. Caixa Postal 593, 38400-902 Uberlândia, Minas Gerais, Brasil. \\ E-mail: heraldo@umuarama.ufu.br \\ 2 Departamento de Biologia Animal, Universidade Federal Rural do Rio de Janeiro. 23890-000 Seropédica, Rio de Janeiro, \\ Brasil. E-mail: amayhe@ufrrj.br
}

\begin{abstract}
Fungus-growing ants (tribe Attini) are characteristic elements of the New World fauna. However, there is little information on the patterns of diversity, abundance, and distribution of attine species in their native ecosystems, especially for the so-called "lower" genera of the tribe. A survey of attine ant nests (excluding Atta Fabricus, 1804 and Acromyrmex Mayr, 1865) was conducted in a variety of savanna and forest habitats of the Cerrado biome near Uberlândia, Brazil. In total, 314 nests from 21 species of nine genera were found. Trachymyrmex Forel, 1893 was the most diverse genus with 10 species. Eighteen species were found in the savannas, including Mycetagroicus cerradensis Brandão \& Mayhé-Nunes, 2001, a species from a recently-described genus of Attini, whereas in the forests only 12 species were found. Forest and savannas support relatively distinct faunas, each with a number of unique species; the species present in the forest habitats did not represent a nested subset of the species found in the savannas. Furthermore, although many species were common to both types of vegetation, their abundances were quite different. The density of attine nests is relatively high at some sites, exceeding an estimated 4,000 nests per hectare. In this sense, attine ants can be regarded as prevalent invertebrate taxa in the Brazilian Cerrado.

KEY WORDS. biodiversity; community structure; forest; savanna; Trachymyrmex.
\end{abstract}

\begin{abstract}
RESUMO. Padrões de diversidade e abundância de formigas cultivadoras de fungo (Formicidade: Attini) em áreas do Cerrado Brasileiro. As formigas cultivadoras de fungos (tribo Attini) são exclusivas da fauna do Novo Mundo. Entretanto, existem poucas informações sobre os padrões de diversidade, abundância e distribuição das espécies de Attini em seus ecossistemas nativos, em especial para os gêneros menos derivados desta tribo. Um levantamento de ninhos de Attini (excluindo Atta Fabricius, 1804 e Acromyrmex Mayr, 1865) foi realizado em diversos ambientes savânicos e de floresta do bioma Cerrado próximos à Uberlândia, Brasil. Encontramos 314 ninhos de 21 espécies pertencentes a nove gêneros da tribo. Trachymyrmex Forel, 1893 foi o gênero mais diverso, com 10 espécies. Encontramos 18 espécies na savana, incluindo Mycetagroicus cerradensis Brandão \& Mayhé-Nunes, 2001, uma espécie de um gênero de Attini recentemente descrito, enquanto que nas áreas de floresta registramos somente 12 espécies. As savanas e florestas apresentaram faunas relativamente distintas, com espécies exclusivas de cada tipo de vegetação; as espécies presentes nas florestas não representaram um subconjunto das espécies encontradas nas savanas. Além disso, apesar de muitas espécies terem sido comuns a ambos os tipos de vegetação, suas abundâncias foram muito diferentes. A densidade estimada de ninhos de Attini foi relativamente alta em alguns locais, ultrapassando 4.000 ninhos por hectare. Neste sentido, as formigas da tribo Attini podem ser consideradas como invertebrados predominantes no Cerrado brasileiro.
\end{abstract}

PALAVRAS-CHAVE. Biodiversidade; estrutura de comunidades. floresta. savana. Trachymyrmex.

Ants of the tribe Attini are characteristic elements of the fauna of the New World. Currently, 13 genera and over 200 species of attine ants are known and all of these species consume fungi as a food source (BRANDÃo \& MAYHÉ-Nunes 2001, Mueller et al. 2001, Bolton 2003). Most of these species have Neotropical distribution, with only $5 \%$ of attine species occur- ring in the Neartic region (MaYhé-Nunes \& Jaffé 1998). Attine ants of Atta Fabricius. 1804 and Acromyrmex Mayr, 1865, known as leaf-cutting ants, build relatively large nests and use fresh leaves for fungus cultivation. On the other hand, the nonleafcutting genera of Attini, known as "basal" or "lower" fungus-growing ants, build relatively small nests and grow their 
fungi on a variety of substrates, including fallen flowers, fruits and seeds, dead vegetal matter, feces of herbivorous insects, and insect corpses (Hölldobler \& Wilson 1990, Leal \& Oliveira 2000). Studies on the ecology of attine ants have traditionally focused on Atta and Acromyrmex, since these are the most conspicuous and economically important members of the group. Yet, a number of studies have indicated that the less conspicuous lower attine ants perform important ecosystem services. For instance, in the Brazilian Atlantic Rain Forest, seed cleaning by Mycocepurus goeldii Forel, 1893 was found to increase the germination rate of Hymenaea courbaril Linnaeus, 1758 seeds (Oliverra et al. 1995). Similarly, in the Cerrado, attine ants act as secondary dispersers of seeds of non-myrmecochorous plants (Christianini et al. 2007) and also increase their germination success (Leal \& Oliveira 1998).

Relatively little information exists on the patterns of diversity, abundance, and distribution of lower attines in their native ecosystems (but see LEAL \& Oliveira 2000). In this study, we performed a survey of attine nests in a variety of savanna and forest habitats of the Cerrado biome in Central Brazil. The Cerrado region is covered by a mosaic of vegetation types, which include mostly savannas of very variable structure (collectively known as cerrado sensu lato) on the well-drained interfluves and forests along the water courses or on richer soils (OliveiraFilho \& Ratter 2002). We evaluated the hypothesis that the attine fauna is more diverse and abundant in the savanna than in the forest habitats of the Cerrado (Leal \& Oliveira 2000). Furthermore, we evaluated whether forest and savannas support a distinct fauna (cf. SABO et al. 2005), or alternatively, whether the fauna of the less diverse habitats represent a nested subset of the most species-rich habitats.

\section{MATERIAL AND METHODS}

The study was conducted at four sites with native vegetation near Uberlândia, Minas Gerais, Brazil. We collected attine ants at: Estação Ecológica do Panga (EEP) (19¹0'S, $\left.48^{\circ} 23^{\prime} \mathrm{W}\right)$, Fazenda Água Limpa (FAL) $\left(19^{\circ} 05^{\prime} \mathrm{S}, 48^{\circ} 21^{\prime} \mathrm{W}\right)$, Fazenda Experimental do Glória (FEG) (18 $\left.56^{\prime} \mathrm{S}, 48^{\circ} 12^{\prime} \mathrm{W}\right)$, and Parque Municipal Victório Siquierolli (PVS) (18 $\left.52^{\prime} \mathrm{S}, 48^{\circ} 15^{\prime} \mathrm{W}\right)$. Collections were performed in four different vegetation types, including two types of forest, the semi-deciduous forest and the cerradão, and two types of savanna vegetation, the cerrado sensu stricto and the campo cerrado (Oliveira-Fillho \& Ratter 2002). Not all study sites presented all these types of vegetation, and therefore the number of vegetation types sampled per site was variable. In total, eight areas were sampled, two of each vegetation type. Within each area, we located and marked all Attini nests (excluding those of Atta and Acromyrmex) found in 40 plots of $4 \mathrm{~m}^{2}$ each $(2 \times 2 \mathrm{~m})$. These plots were distributed uniformly along two 200-m long transects, with a spacing of $10 \mathrm{~m}$ between plots. In total 320 plots were established, covering an area of $1,280 \mathrm{~m}^{2}$. To facilitate the location of the ant nests we put, within each plot, four baits made of corn flour and dried orange peel. The plots were baited twice, once in the morning and once in the afternoon. Once the ants retrieved the baits, foragers were followed back to their nest entrance. Only nests located within the plots were marked. Voucher specimens are deposited in the entomological collection of Universidade Federal de Uberlândia (UFU), and in the Coleção Entomológica Costa Lima (CECL) of the Universidade Federal Rural do Rio de Janeiro (UFRRJ).

For each of the eight sampling areas we determined the number of ant species, the absolute and relative number of ant nests per species, and the total number of ant nests (for all species combined). Differences in species richness and in nest density between forest and savanna habitats were evaluated using ttests. Data on nest densities in each sampling area were log transformed prior to analysis in order to meet the assumptions of data normality. The relationship between nest densities and species richness was evaluated using simple linear regression.

We calculated the similarity in ant species composition among the eight sampled areas using the following formula: $\mathrm{PS}=\Sigma(\mathrm{p} 1 \mathrm{i} ; \mathrm{p} 2 \mathrm{i}) \times 100$, where 'PS' is the percentage of similarity between any two areas, 'p1i' is the relative abundance of species ' $\mathrm{i}$ ' in area ' 1 ' and ' $\mathrm{p} 2 \mathrm{i}$ ' is the relative abundance of species ' $i$ ' in area ' 2 ', and $\Sigma$ is the sum of the values (BROWER \& ZAR 1977). With the resulting similarity values we constructed a cluster tree using the average linkage method (Spss 2000).

We calculated the degree of nestedness of ant assemblages from different sampling areas with the Nestedness Temperature Calculator Program (Atmar \& Patterson 1995). This method estimates the maximum nestedness in a given matrix (of species by areas) by re-arranging ant species and sampling areas in such a way as to minimize unexpected species occurrences (Atmar \& Patterson 1993). The degree of nestedness is calculated by the temperature index $\left(\mathrm{T}^{\circ}\right)$ of the matrix, which ranges from $0^{\circ}$ for a perfectly nested matrix, to $100^{\circ}$ for a random matrix. The significance of the observed temperature index value was determined through a randomization procedure with 100 iterations (AtMAR \& Patterson 1995).

\section{RESULTS}

In total, 314 nests from 21 species of nine genera were found. Trachymyrmex Forel, 1893 was the most diverse genus, with a total of 10 species. The remaining genera all presented only one to two species each. In terms of numerical abundance, Trachymyrmex, Sericomyrmex, and Mycocepurus were the dominant genera, with 92, 88, and 80 nests respectively. Mycetosoritis and Mycetagroicus were the rarest, with only 1 and 6 nests, respectively.

The largest number of nests was found in the Estação Ecológica do Panga cerrado sensu stricto, whereas the lowest was in the cerradão of the same site (Tab. I). In the former we found 66 nests in $160 \mathrm{~m}^{2}$, whereas in the latter only 27 nests. These numbers are equivalent to a density of 4,125 and 1,688 nests per hectare, respectively. Comparing the savanna and 
Table I. Nest densities of attine species in two savanna habitats (campo cerrado and cerrado sensu stricto) and in two forest habitats (cerradão and semi-deciduous forest) in different sites near Uberlândia, Brazil. Values represent the number of nests in 160 m² (40 plots of $4 \mathrm{~m}^{2}$ each).

\begin{tabular}{|c|c|c|c|c|c|c|c|c|}
\hline \multirow{2}{*}{ Ant species } & \multicolumn{2}{|c|}{ Campo Cerrado } & \multicolumn{2}{|c|}{$\begin{array}{l}\text { Cerrado sensu } \\
\text { stricto }\end{array}$} & \multicolumn{2}{|c|}{ Cerradão } & \multicolumn{2}{|c|}{$\begin{array}{c}\text { Semideciduous } \\
\text { forest }\end{array}$} \\
\hline & $\mathrm{EEP}^{1}$ & $\mathrm{FAL}^{2}$ & EEP & FAL & EEP & $\mathrm{PVS}^{3}$ & EEP & $\mathrm{FEG}^{4}$ \\
\hline Apterostigma gr. pilosum sp. 1 & 0 & 0 & 2 & 0 & 2 & 5 & 2 & 0 \\
\hline Apterostigma gr. pilosum sp. 2 & 1 & 0 & 0 & 0 & 1 & 0 & 0 & 0 \\
\hline Cyphomyrmex aff. major Forel, 1901 & 0 & 1 & 1 & 0 & 1 & 2 & 1 & 6 \\
\hline Mycetagroicus cerradensis Brandão \& Mayhé-Nunes, 2001 & 2 & 0 & 4 & 0 & 0 & 0 & 0 & 0 \\
\hline Mycetarotes parallelus Emery, 1905 & 0 & 0 & 0 & 0 & 1 & 0 & 0 & 0 \\
\hline Mycetosoritis sp. & 0 & 1 & 0 & 0 & 0 & 0 & 0 & 0 \\
\hline Mycocepurus goeldii Forel, 1893 & 16 & 15 & 19 & 25 & 0 & 0 & 0 & 0 \\
\hline Mycocepurus smithii Forel, 1893 & 1 & 1 & 1 & 2 & 0 & 0 & 3 & 3 \\
\hline Myrmicocrypta sp. & 0 & 1 & 9 & 1 & 0 & 1 & 3 & 0 \\
\hline Sericomyrmex aff. scrobifer Forel, 1911 & 0 & 1 & 3 & 1 & 21 & 18 & 26 & 17 \\
\hline Sericomyrmex sp. & 0 & 0 & 0 & 0 & 0 & 0 & 1 & 0 \\
\hline Trachymyrmex agudensis Kempf, 1967 & 0 & 2 & 0 & 0 & 0 & 0 & 0 & 0 \\
\hline Trachymyrmex cirratus Mayhé-Nunes \& Brandão, 2005 & 0 & 0 & 3 & 0 & 0 & 0 & 0 & 0 \\
\hline Trachymyrmex dichrous Kempf, 1967 & 6 & 3 & 0 & 0 & 0 & 0 & 0 & 0 \\
\hline Trachymyrmex holmgreni Wheeler, 1925 & 3 & 9 & 0 & 3 & 0 & 1 & 0 & 0 \\
\hline Trachymyrmex ruthae Weber, 1937 & 0 & 2 & 2 & 0 & 0 & 0 & 0 & 0 \\
\hline Trachymyrmex aff. levis Weber, 1938 & 0 & 0 & 0 & 0 & 1 & 1 & 7 & 8 \\
\hline Trachymyrmex papulatus Santschi, 1922 & 0 & 0 & 2 & 0 & 0 & 0 & 0 & 0 \\
\hline Trachymyrmex gr. cornetzi sp. 1 & 1 & 3 & 0 & 1 & 0 & 0 & 0 & 0 \\
\hline Trachymyrmex gr. urichi sp. 1 & 1 & 4 & 8 & 2 & 0 & 0 & 0 & 3 \\
\hline Trachymyrmex gr. urichi sp. 2 & 0 & 0 & 12 & 1 & 0 & 3 & 0 & 0 \\
\hline
\end{tabular}

${ }^{1}$ Estação Ecológica do Panga, ${ }^{2}$ Fazenda Água Limpa, ${ }^{3}$ Parque Municipal Victorio Siqueirolli, ${ }^{4}$ Fazenda Experimental do Glória.

forest habitats, we did not find a significant difference in nest densities (mean \pm 1 . S.D. number of nests in $160 \mathrm{~m}^{2}$, Forest: = $34.5 \pm 7.0$, Savanna: $=44.0 \pm 15.5 ; \mathrm{t}=1.12, \mathrm{df}=6, \mathrm{p}=0.30$ ). However, there were significantly more species in the savanna than in the forest habitats (mean \pm 1 . S.D. number of species in $160 \mathrm{~m}^{2}$, Forest: $6.2 \pm 1.0$, Savanna: $10.0 \pm 2.3 ; \mathrm{t}=3.0, \mathrm{df}=6, \mathrm{p}=$ $0.024)$. There was a trend towards finding more species in areas with a greater density of ant nests $\left(\mathrm{r}^{2}=0.50, \mathrm{~F}_{1,6}=5.98, \mathrm{p}=\right.$ 0.05 , Fig. 1). However, differences in nest densities can not explain the observed differences in species richness between forest and savanna habitats, as even when densities were comparable, the latter always presented a higher species richness than the former (Fig. 1).

The distribution of species among sampling sites was not significantly nested $\left(\mathrm{T}^{\mathrm{o}}{ }_{\text {observed }}=35.08^{\circ}, \mathrm{T}^{\mathrm{o}}{ }_{\text {random }}=47.28^{\circ}, \mathrm{SD}=\right.$ $8.28, \mathrm{p}=0.071$ ), indicating that the species present in the less species-rich sites did not represent a nested subset of the species found in the richest sites. The sites with fewer species were all forest sites, but some of the species present in the forest, such as Mycetarotes paralellus Emery, 1905, Sericomyrmex sp.,

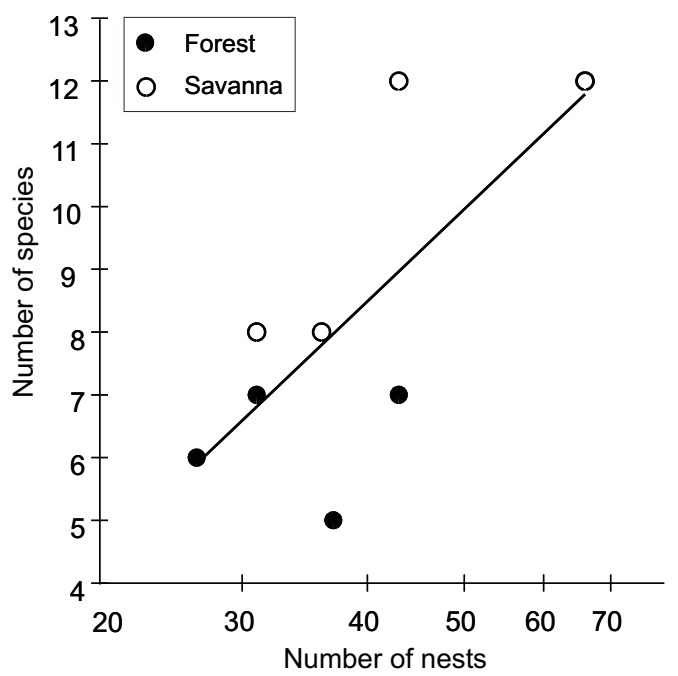

Figure 1. Relationship between nest abundance and diversity of attine ants. Each point represents the total number of nests and total number of species found within 40 plots of $4 \mathrm{~m}^{2}$ each. 
and Trachymyrmex aff. levis (Tab. I), were not present in the savanna. Furthermore, Sericomyrmex aff. scrobifer, the most abundant species in the forest habitats, was rare in the savanna, whereas Mycocepurus goeldii, the most common species in the savanna, was not found in the surveyed forest sites (Tab. I). As a result, we observed clear differences in the composition of the attine ant fauna between savanna and forests (Fig. 2). Differences in species composition between the two forest habitats surveyed, the cerradão and the semi-deciduous forest, were also detected, whereas differences between the two savanna habitats, the campo cerrado and the cerrado sensu stricto were less clear (Fig. 2).

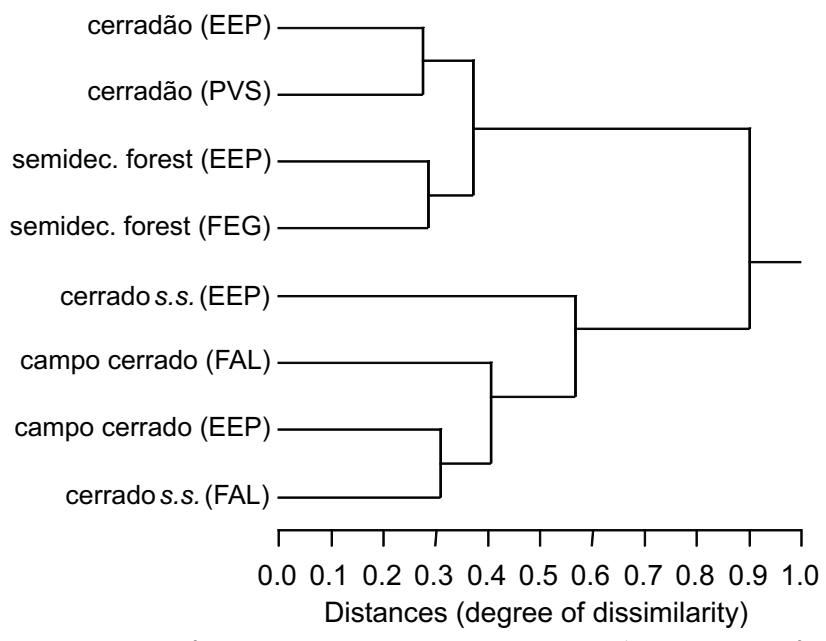

Figure 2. Dendrogram comparing two savanna (campo cerrado and cerrado sensu stricto) and two forest habitats (cerradão and semi-deciduous forest) with regard to the composition of the attine ant fauna. (EEP) Estação Ecológica do Panga, (FAL) Fazenda Água Limpa, (PVS) Parque Municipal Victorio Siqueirolli, (FEG) Fazenda Experimental do Glória. Distances $=1-$ Percentage of Similarity.

\section{DISCUSSION}

The results of this study reinforce the earlier findings of Leal \& Oliveira (2000), who suggested that, in the Cerrado biome, the attine fauna is more diverse in the savanna habitats than in the adjacent forest habitats. Similarly, in northern Australia, ANDERSEN et al. (2007) recorded a much higher number of ant species in the savanna than in the adjacent patches of rain forest. In contrast, in the savannas of eastern Amazonia the diversity of ant species is much lower compared to the diversity of species in the adjacent forest habitats, and this trend is also observed when considering only ants of the tribe Attini (VAsconcelos \& Vilhena 2006). This difference may be attributed to the fact that, in the Cerrado (as well as in northern Australia; ANDERSEn et al. 2007) savanna is the dominant type of vegetation, whereas in the eastern Amazon savannas occur as isolated patches within a large forested region. Thus, the regional pool of savanna ant species is perhaps much greater in central Brazil than it is in the Amazon, whereas the reverse pattern is probably true for the forest species.

Of the 21 species recorded here, 18 were present in the savanna habitats, including Mycetagroicus cerradensis Brandão \& Mayhé-Nunes, 2001, a species from a recently-described genus of Attini (Brandão \& MaYhé-NunEs 2001), whereas in the forest sites only 12 species were found. Similarly, the mean number of species per transect was nearly two times higher in the savannas than in the forests. Most of the difference in species richness between these two vegetation types was due to the elevated number of Trachymyrmex species in the savanna (9 species versus only four in the forest), as also evidenced in the study of Leal \& Oliveira (2000). The distribution of attine species is still poorly known, but MAYHÉ-Nunes \& JAFFé (1998) observed that the highest number of Trachymyrmex species is found near the Equator (between $10^{\circ} \mathrm{S}$ and $\left.10^{\circ} \mathrm{N}\right)$. However, they pointed out that about half of the attine species are only known from type localities, suggesting that this group is still largely under-sampled. It therefore seems likely that the diversity of Trachymyrmex in the Cerrado may have been underestimated. In fact, some recent studies on Trachymyrmex have demonstrated that many species previously thought to be geographically restricted or known only from type localities actually have wider geographic distributions (MAYHé-Nunes \& BRANDÃo 2002, 2005, 2007). This also seems to be the case for at least three of the Trachymyrmex species found in Uberlândia, namely T. agudensis Kempf, 1967, T. cirratus Mayhé-Nunes \& Brandão, 2005, and T. papulatus Santschi, 1922, which were previously known only from a few localities. In particular, our collection of T. agudensis is the first of this species after its original description (KempF 1967), and extends its range by $4^{\circ}$ of latitude.

Forest and savannas supported relatively distinct faunas (cf. VASCONCELOS \& VilHeNa 2006), each with a number of unique species. Therefore, although there were fewer species in the forest than in the savannas, the species present in the former habitat did not represent a nested subset of the species found in the latter habitat. Furthermore, although many species were common to both types of vegetation, their abundances were quite different. For instance, the average density of Sericomyrmex aff. scrobifer nests was about 16 times higher in the forest than in the savanna habitats (Tab. I). In the savannas, the most common species was Mycocepurus goeldii, where up to 25 nests were found in only $160 \mathrm{~m}^{2}$. Similarly, KempF (1963) observed that $M$. goeldii is very common in the region of Agudos, São Paulo (the type locality of T. agudensis found by us in Uberlândia), where it occasionally lives alongside its close relative M. smithii Forel, 1893. Although M. goeldii was not collected in the forest sites surveyed here, previous studies indicate that it can also be found in gallery forest and in semi-deciduous forest (OLIVEIRA et al. 1995, Leal \& Oliveira 2000). Both M. goeldii and Sericomyrmex spp. also reach relatively elevated densities in Eucalyptus plantations, where they can cause some economic damage (ZANETTI et al. 2003). 
Despite containing a higher number of species, the savanna sites surveyed here did not support a significantly greater density of attine ant nests than did the forest sites. Therefore, the relatively low diversity of attine ants in the forests near Uberlândia can not be attributed to a paucity of ant nests. This contrasts with the results from LeAL \& OLIVEIRA (2000) who observed not only a higher diversity but also a greater abundance of attine ants in the savanna than in the forest habitats. The difference between their study and ours may be due to differences in the types of forest analyzed in each study. We surveyed ants in two upland forest habitats: the cerradão and the semi-deciduous forest, whereas LeAL \& OLIVEIRA (2000) worked closer to the valley, in the gallery forest, where occasional flooding may limit the establishment of ant nests on the ground (cf. Lopes \& VASCONCElos 2008). Nevertheless, both studies indicate that the density of attine nests in the Brazilian Cerrado is relatively high. In fact, our estimates indicate that more than 4,000 nests can be found in a single hectare in some areas. In this sense, attine ants can be regarded as prevalent invertebrate taxa in the Cerrado ecosystems and, given their antagonistic and mutualistic interactions with plant diaspores (Leal \& OliverRA 1998), may well have an important influence on the structure and dynamics of the vegetation.

\section{ACKNOWLEDGMENTS}

We thank the Universidade Federal de Uberlândia for logistical support, Alan N. Costa and Cauê T. Lopes for assistance during fieldwork, and Scott Solomon for comments on the manuscript. Financial support was provided by the Fundação de Amparo a Pesquisas de Minas Gerais (CRA-1419/ 05) and the Conselho Nacional de Pesquisas e Desenvolvimento Científico e Tecnológico (fellowships to HLV and AJMN).

\section{LITERATURE CITED}

Andersen, A.N.; van Ingen, L.T. \& R.I. Campos. 2007. Contrasting rainforest and savanna ant faunas in monsoonal northern Australia: a rain forest patch in a tropical savanna landscape. Australian Journal of Zoology 55: 363-369.

Atmar, W. \& B.D. Patterson. 1993. The measure of order and disorder in the distribution of species in fragmented habitats. Oecologia 96: 373-382.

Atmar, W. \& B.D. Patterson. 1995. The nestedness temperature calculator. AICS Res. Inc., available online at http:/aicsresearch.com/nestedness/tempcalc.html [Acessed in 13.08.2004]

Bolton, B. 2003. Synopsis and Classification of Formicidae. Gainesville, Memoirs of the American Entomological Institute, vol. 71, 370p.

Brandão, C.R.F. \& A.J. MaYhé-Nunes. 2001. A new fungus-growing ant genus, Mycetagroicus gen. n., with the description of three new species and comments on the monophyly of the Attini (Hymenoptera: Formicidae). Sociobiology 38: 639-665.
Brower, J.E. \& J.H. Zar. 1977. Field and laboratory methods for general ecology. Dubuque, WM.C. Brown Company Publishers, VI+194p.

Christianini, A.V.; A.J. Mayhé-Nunes \& P.S. Oliveira. 2007. The role of ants in the removal of non-myrmecochorous diaspores and seed germination in a neotropical savanna. Journal of Tropical Ecology 23: 343-351.

Hölldobler B. \& E.O. Wilson. 1990. The Ants. Cambridge, Belknap Press, XX+732p.

Kempf, W.W. 1963. A review of ant genus Mycocepurus Forel, 1893 (Hymenoptera: Formicidae). Studia Entomologica 6: 417-432.

KempF, W.W. 1967. New ants from southwestern and central Brazil. Studia Entomologica 9: 121-128.

LeaL, I.R. \& P.S. Oliveira. 1998. Interactions between fungusgrowing ants (Attini), fruits and seeds in cerrado vegetation in Southeast Brazil. Biotropica 30: 170-178.

Leal, I.R. \& P.S. Oliveira. 2000. Foraging ecology of attine ants in a Neotropical savanna: seasonal use of fungal substrate in the cerrado vegetation of Brazil. Insectes Sociaux 47: 376-382.

Lopes, C.T. \& H.L. Vasconcelos. 2008. Evaluation of three methods for sampling ground-dwelling ants in the Brazilian Cerrado. Neotropical Entomology 37 (4).

Mayhé-Nunes, A.J. \& K. JafFé. 1998. On the biogeography of Attini (Hymenoptera: Formicidae). Ecotropicos 11: 45-54.

Mayhé-Nunes, A.J. \& C.R.F. Brandão. 2002. Revisionary studies on the attine ant genus Trachymyrmex Forel. Part 1: definition of the genus and the Opulentus group (Hymenoptera: Formicidae). Sociobiology 40: 667-698.

MaYhé-Nunes, A.J. \& C.R.F. BRAndão. 2005. Revisionary studies on the attine ant genus Trachymyrmex Forel. Part 2: the Iheringi group (Hymenoptera: Formicidae). Sociobiology 45: $1-35$.

Mayhé-Nunes, A.J. \& C.R.F. Brandão. 2007. Revisionary studies on the attine ant genus Trachymyrmex Forel. Part 3: The Jamaicensis group (Hymenoptera: Formicidae). Zootaxa 1444: 1-21.

Müeller, U.G.; T.R. Schultz; C.R. Currie; R.M.M. Adams \& D. Malloch. 2001. The origin of the attine ant-fungus mutualism. The Quarterly Review of Biology 76: 169-197.

Oliveira-Filho A.T. \& J.T. RatTer. 2002. Vegetation physiognomies and woody flora of the cerrado biome, p. 91-120. In: P.S. Oliveira \& R.J. Marquis (Eds). The Cerrados of Brazil: ecology and natural history of a Neotropical savanna. New York, Columbia University Press, XVIII+398p.

Oliveira, P.S; M. Galetti; F.E. Pedroni \& L.P.C. Morellato. 1995. Seed cleaning by Mycocepurus goeldii ants (Attini) facilitates germination in Hymenaea courbaril (Casealpiniaceae). Biotropica 27: 518-522.

Sabo, J.L.; R. Sponseller; M. Dixon; K. Gade; T. Harms; J. Heffernan; A. Jani; G. Katz; C. Soykan; J. Wattes \& J. Welter. 2005. Riparian zones increase regional species richness by 
harboring different, not more, species. Ecology 86: 56-62. Spss. 2000. Systat version 10. San Francisco, SPSS Inc.

Vasconcelos, H.L. \& J.M.S. Vilhena. 2006. Species turnover and vertical partitioning of ant assemblages in the Brazilian Amazon: a comparison of forests and savannas. Biotropica
38: 100-106.

Zanetti, R.; J.C. Zanuncio; A.J. Mayhé-Nunes; A.G.B. Medeiros \& A. Souza-Silva. 2003. Combate sistemático de formigascortadeiras com iscas granuladas, em eucaliptais com cultivo mínimo. Revista Árvore 27: 387-392.

Submitted: 01.VI.2008; Accepted: 29.VIII.2008.

Editorial responsibility: Márcio R. Pie 